\title{
Non-Surgical Castration in Bucks A Comparative Study between Chemical Castration and External Ligation of the Spermatic Cord
}

\author{
R. N. Al-Asadi Kh. K. Al-Kadi \\ Coll. of Vet. Med./ Unive of Baghdad
}

\begin{abstract}
This study aimed to evaluate the effectiveness of intra-testicular injection of formalin and external ligation of the spermatic cord in inducing sterilization in bucks. Twelve's adult bucks were used which allocated randomly and equally into three groups. The first group served as a control group injected (5) $\mathrm{ml}$ distilled water intra-testicular, while the second group injected (5) $\mathrm{ml}$ of $3 \%$ formalin and in the third group external ligation of spermatic cord with silk was used.Blood samples were collected from all bucks prior and post to treatment to assay serum testosterone level. In addition, semen samples were collected via artificial vagina to evaluate some semen parameters.Clinical follow-up of animals revealed no any secondary complications in control group, while treatment group showed certain minor complications such as testicular swelling, hydrocele, scrotal ulcer and lameness which disappeared in a short time.Results indicated that testosterone level were significantly decline $\mathrm{P}<0.05$ in the second and third groups, it reached to $(0.30 \pm 0.05)$ and $(1.66 \pm 0.25) \mathrm{ng} / \mathrm{ml}$ respectively at the end of experiment.All semen parameters were significantly $\mathrm{P}<0.05$ decreased on days 21 and 28 in treatment groups, in which there was seminal plasma only, absence of sperm motility, zero sperm concentration and no viable sperms.All animals subjected to traditional castration on 30 and 60 days post-injection or ligation to harvested testicular biopsies for histopathological examination. Testicular sections revealed depletion of sertoli cells and interstitial fibrosis which replaced leydig cells. These changes were more severe in chemical group when compared with ligation group. This means that both techniques reflected their ability to impair or stop the testicular functions with superiority of chemical castration.
\end{abstract}

Keywords: - Non-surgical castration, Chemical, External ligation, Spermatic cord, bucks

\section{Introduction}

Castration is performed on normal or diseased testes either by surgical type (removal of the testes) or non-surgical methods which cause degeneration of the testes resulting in sterilization such as the using of burdizzo or new options (chemical or immunological castration)(1).Castration has been done for several reasons e.g. improving meat quality, unwanted pregnancies, docility, reduce the spread of inferior genetic traits and treatment of some testicular diseases (2).Testis is composed of an exocrine part (seminiferous tubules), which are lined by a stratified epithelium that consist of developing spermatozoa and supporting cells (sertoli cells). The endocrine part (interstitial or leydig cells) are responsible for synthesis and secretion of the steroid hormones (testosterone) (3).Effort to find chemical agent that causing sclerosis of the testis started with American pig farmers where the objective was to reduce the bad taint that develops in adult boar meat due to androgen action (4). Also a variety of chemical agents and mixtures have been studies in ruminant such as lactic acid, silver nitrate, calcium chloride, ethanol and phenol, these agents injected intratesticular (1),(5).In the present research we tried to find field, safe, simple, rapid and inexpensive techniques represented by intra-testicular injection of formalin and external ligation of spermatic cord to find which method is the most effective in inducing sterilization based on clinical, laboratory and histo-pathological evaluations.
Experimental Animals:

\section{Materials and Methods}

Twelve apparently healthy adult bucks, aged 2 to 3 years and weighing 
$30 \pm 3.5 \mathrm{Kg}$., with normal libido and serving ability were used. Bucks were allocated randomly into three groups (4 bucks/group) as follows:

1. First group: serve as control group injected distilled water intra-testicularly.

2. Second group: subjected to intratesticular injection of $3 \%$ formalin.

3. Third group: double external ligation of the spermatic cord was performed.

Technique of Intra-testicular Injection:

The testis and surrounding inguinal region were prepared for aseptic injection. Animal put on the lateral position with the help of xylazine hydro-chloride $2 \%$ in a dose of $0.2 \mathrm{mg} / \mathrm{kg} \mathrm{B.W}$., administered I.M. The needle introduced from the caudal pole of the testis toward the cranial pole and the agent was distributed equally $(1 \mathrm{ml} / \mathrm{cm})$ along the line of injection (Figure 1). The dose was (5) $\mathrm{ml}$ distilled water for the first group and the same dose of $3 \%$ formalin injected in the second group. The dose estimated clinically according to the testicular length. The same technique was repeated on the contra-lateral testis.

Technique of External Ligation:

The skin enveloped the spermatic cord was prepared for aseptic ligation. Animal restrained on lateral position, then local subcutaneous infiltration of lidocaine hydrochloride $2 \%$ at the sites of ligation in a dose of $1 \mathrm{mg} / \mathrm{kg}$. B.W. Double external trans-fixing ligation of whole spermatic cord, $2 \mathrm{~cm}$ apart was done using nonabsorbable suture materials (silk No.1). The same technique was repeated on the other cord (Figure 2).

\section{Assessment of Serum Testosterone Concentration:}

Blood samples were collected by jugular venapuncture from the three groups prior to intra-testicular injection or ligation, then on days 7, 14, 21 and 28 post injections or ligation. Serum samples were obtained by centrifugation $3000 \mathrm{rpm}$ for 15 minutes. Serum testosterone levels were determined by radioimmunoassay (6).

\section{Semen Collection:}

Semen was collected from all bucks using an artificial vagina at the periods mention for measurement of the testosterone values. Some semen parameters were evaluated according to technique used by (7). These include ejaculate volume, sperm motility, sperm concentration and sperm viability.

\section{Pathological Examination:}

Testes were removed by surgical castration from all animals at one and two methods post intra-testicular injection or ligation. Testicular biopsy $1 \mathrm{~cm}^{3}$ from each animal was harvested, fixed in $10 \%$ neutral buffered formalin, then dehydrated in graded levels of alcohol, embedded in paraffin wax and sectioned by a microtone at 5-6 $\mu \mathrm{m}$ thick. The slides were stained with Hematoxylin-Eosin ( $\mathrm{H}$ and $\mathrm{E})$ stain (8). The structures of the seminiferous tubules and interstitial space of the testes were examined under light microscope (x10).

\section{Statistical Analysis:}

Means and standard error $(\mathrm{M} \pm \mathrm{SE})$ were calculated for each group. Two Way Analysis of Variance (ANOVA) was used to determine the differences between mean control and treatment values of serum testosterone concentration and values of semen parameters. Also least significant differences (LSD) test was used to significant comparative between means $\mathrm{P}<0.05$ (9). 


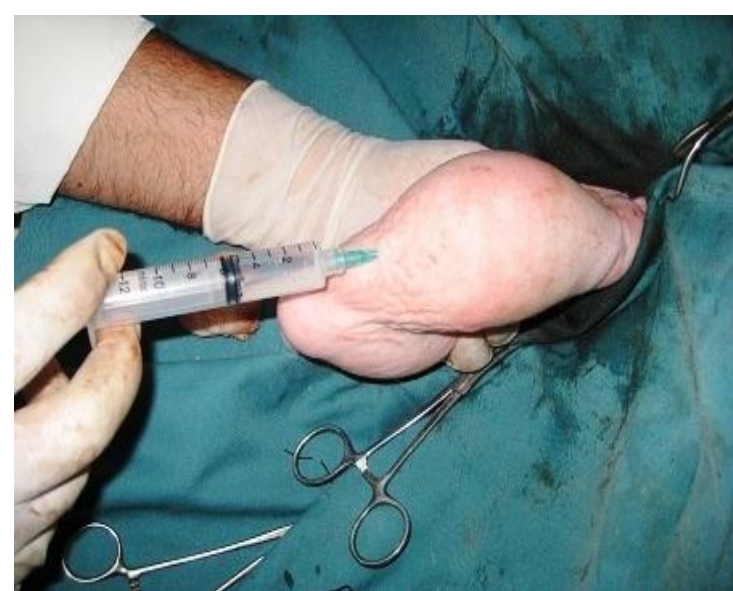

Figure (1) Technique of intratesticular injection. Figure (2). Technique of external ligation of the spermatic cord.

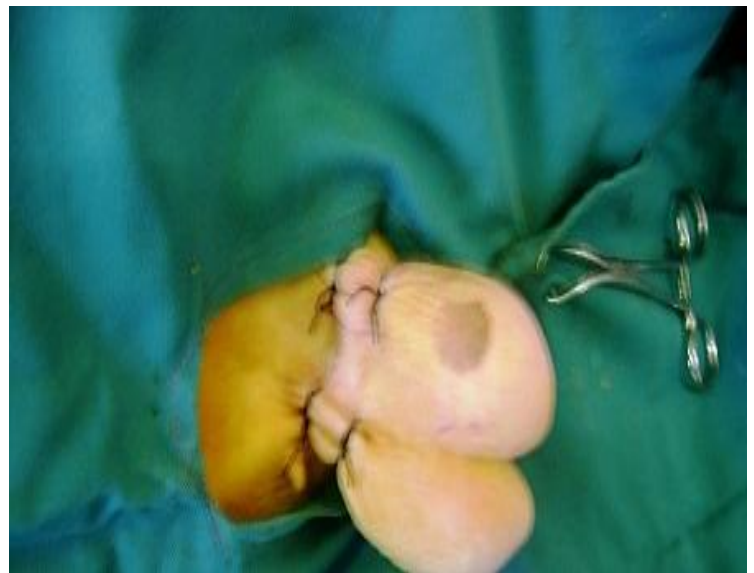

\section{Results}

\section{Duration of Techniques:}

Intra-testicular injection of distilled water or formalin required (40-50) seconds mean (45) seconds/testis, while external ligation necessitated longer time (2-3) minutes mean (2.5) minutes /testis.

\section{Clinical Follow-up:}

Table (1). The secondary complications post formalin injection and external ligation.

\begin{tabular}{|l|c|c|c|}
\hline \multirow{2}{*}{ Complications type } & \multicolumn{2}{|c|}{ Technique and number of affected animals } & \multirow{2}{*}{ Response to treatment } \\
\cline { 2 - 3 } & Formalin group & Ligation group & \\
\hline Testicular swelling & All & All & + \\
\hline Hydrocele & - & 2 & + \\
\hline Scrotal ulcer & 2 & - & + \\
\hline Lameness & 1 & 4 & + \\
\hline
\end{tabular}

The testes became swollen and tender in all treated bucks shortly after recovery from operation. The size of each testis was the largest on days (2-4) post injection or ligation. This phenomenon gradually recedes to normal size on the $5^{\text {th }}$ day in chemical group and on $7^{\text {th }}$ day in ligation group.Hydrocele which means accumulation of serous fluid between the two layers of tunica vaginalis was detected in two bucks related to ligation group. The fluid was aseptically aspirated twice daily for three days which resulted in a positive effect.Scrotal ulcer was noticed in two animal related to chemical group. The first
All bucks were followed-up clinically during the study period to record any abnormalities. In control group, no adverse reaction reported although the testis was visibly edematous. The remaining two groups reflected certain secondary health problems (Table 1). animal showed a large reddened area on the scrotum on day post- injection. It responds to topical treatment and the lesion healed after five days. While the second animal and on day eight post- injection reflected necrosis of one half of the scrotum and the testis was exposed. The testis surgically removed.The common complication was lameness which took place in five bucks soon after recovery from analgesia. It treated with pain suppression (metalgin) in a dose of 5 $\mathrm{mg} / \mathrm{kg}$., I.M. for three days.

Serum Testosterone Concentration: 
The base line value of serum testosterone concentration were not significantly differ $\mathrm{P}>0.05$ in animals related to control group, while differences were obvious $\mathrm{P}<0.05$ among the animals of control and treatment groups (Table 2).
The two various techniques caused a significant drop $\mathrm{P}<0.05$ in serum testosterone concentration which reached $(0.30 \pm 0.05) \mathrm{ng} / \mathrm{ml}$ and $(1.66 \pm 0.25) \mathrm{ng} / \mathrm{ml}$ in chemical and ligation groups respectively on 28 days of experiment.

Table (2). Control and treatment values of serum testosterone concentration (ng/ml) in bucks.

$\mathrm{LSD}=0.437$

\begin{tabular}{|c|c|c|c|}
\hline Time (day) & $\begin{array}{c}\text { Control group } \\
\mathrm{M} \pm \mathrm{SE}\end{array}$ & $\begin{array}{c}\text { Chemical group } \\
\mathrm{M} \pm \mathrm{SE}\end{array}$ & $\begin{array}{c}\text { Ligation group } \\
\mathrm{M} \pm \mathrm{SE}\end{array}$ \\
\hline 7 & A $6.35 \pm 0.17 \mathrm{a}$ & B $2.35 \pm 0.03 \mathrm{a}$ & C $4.67 \pm 0.38$ a \\
\hline 14 & A $6.20 \pm 0.10 \mathrm{a}$ & B $1.75 \pm 0.01 \mathrm{~b}$ & C $3.46 \pm 0.42 \mathrm{~b}$ \\
\hline 21 & A $6.25 \pm 0.15$ a & B $0.96 \pm 0.02 \mathrm{c}$ & C $2.78 \pm 0.33 \mathrm{c}$ \\
\hline 28 & A $6.15 \pm 0.18$ a & B $\quad 0.30 \pm 0.05 \mathrm{~d}$ & C $1.66 \pm 0.25 \mathrm{~d}$ \\
\hline
\end{tabular}

Capital letters denote differences $\mathrm{P}<0.05$ among groups.

Small letters denote differences $\mathrm{P}<0.05$ between means.

\section{Semen Parameters:}

\section{Ejaculate Volume:}

Variable of semen ejaculate of the three groups were present in table (3). In control group, lack of significance $\mathrm{P}>0.05$ in semen volume was observed during the fourth periods although the large volume obtained in the first ejaculate $(1.00 \pm 0.20)$ $\mathrm{ml}$. In chemical group and during 7 and 14 days post- injection the values $(0.60 \pm 0.01)$ and $(0.40 \pm 0.20)$ indicate semen volume (sperm and seminal plasma), while the values $(0.20 \pm 0.00)$ and $(0.10 \pm 0.00)$ on days 21 and 28 referred to seminal plasma only. In contrast, the seminal plasma $(0.20 \pm 0.00)$ was noticed on day 28 in ligation group.

Table (3). Control and treatment values of ejaculate volume ( $\mathrm{ml})$ in bucks.

$\mathrm{LSD}=0.33$

\begin{tabular}{|c|c|c|c|}
\hline Time (day) & $\begin{array}{c}\text { Control group } \\
\mathrm{M} \pm \mathrm{SE}\end{array}$ & $\begin{array}{c}\text { Chemical group } \\
\mathrm{M} \pm \mathrm{SE}\end{array}$ & $\begin{array}{c}\text { Ligation group } \\
\mathrm{M} \pm \mathrm{SE}\end{array}$ \\
\hline 7 & A $1.00 \pm 0.20 \mathrm{a}$ & B $\quad 0.60 \pm 0.10$ a & $\begin{array}{ll}\text { C } & 0.80 \pm 0.20 \mathrm{a}\end{array}$ \\
\hline 14 & A $0.90 \pm 0.10 \mathrm{a}$ & $\begin{array}{lll}\text { B } & 0.40 \pm 0.20 & b \\
\end{array}$ & C $0.65 \pm 0.10 \mathrm{~b}$ \\
\hline 21 & A $0.90 \pm 0.20 \mathrm{a}$ & B $0.20 \pm 0.00 * \mathrm{c}$ & C $0.30 \pm 0.00 \mathrm{c}$ \\
\hline 28 & A $0.89 \pm 0.05 \mathrm{a}$ & B $0.10 \pm 0.00 * \mathrm{c}$ & C $0.20 \pm 0.00 * \mathrm{c}$ \\
\hline
\end{tabular}

Capital letters denote differences $\mathrm{P}<0.05$ among groups.

Small letters denote differences $\mathrm{P}<0.05$ between means.

* Seminal plasma only

\section{Sperm Motility:}

The individual motility (table 4) and the mass motility (table 5) were absent on day 21 in chemical group and on day 28 in ligation group.

Table (4). Shows the values of individual motility (\%) in bucks.

\begin{tabular}{|c|c|c|c|}
\hline Time (day) & $\begin{array}{c}\text { Control group } \\
\mathrm{M} \pm \mathrm{SE}\end{array}$ & $\begin{array}{c}\text { Chemical group } \\
\mathrm{M} \pm \mathrm{SE}\end{array}$ & $\begin{array}{c}\text { Ligation group } \\
\mathrm{M} \pm \mathrm{SE}\end{array}$ \\
\hline 7 & A $80.25 \pm 4.42 \mathrm{a}$ & В $33.50 \pm 6.72$ a & C 53.32 $\pm 5.75 \mathrm{a}$ \\
\hline 14 & A $75.50 \pm 5.15$ a & B $15.00 \pm 2.55 \mathrm{~b}$ & C $30.17 \pm 3.80 \mathrm{~b}$ \\
\hline 21 & A $80.60 \pm 6.32$ a & B $0.00 \pm 0.00 \quad \mathrm{c}$ & C $10.35 \pm 2.25 \mathrm{c}$ \\
\hline 28 & A $75.35 \pm 2.75 \mathrm{a}$ & В $0.00 \pm 0.00$ & $\begin{array}{ll}\text { C } & 0.00 \pm 0.00\end{array}$ \\
\hline
\end{tabular}

$\mathrm{LSD}=12.50$

Capital letters denote differences $\mathrm{P}<0.05$ among groups.

Small letters denote differences $\mathrm{P}<0.05$ between means. 
Table (5). Shows the values mass motility (\%) in bucks.

\begin{tabular}{|c|c|c|c|}
\hline Time (day) & $\begin{array}{c}\text { Control group } \\
\mathrm{M} \pm \mathrm{SE}\end{array}$ & $\begin{array}{c}\text { Chemical group } \\
\mathrm{M} \pm \mathrm{SE}\end{array}$ & $\begin{array}{l}\text { Ligation group } \\
\qquad \mathrm{M} \pm \mathrm{SE}\end{array}$ \\
\hline 7 & A $82.15 \pm 3.40$ a & B $35.50 \pm 2.18$ a & C $55.25 \pm 3.38$ a \\
\hline 14 & A $80.27 \pm 2.32 \mathrm{a}$ & B $17.50 \pm 3.22 \mathrm{~b}$ & C $32.16 \pm 2.56 \mathrm{~b}$ \\
\hline 21 & A $78.75 \pm 4.45$ a & $\begin{array}{lll}\text { B } & 0.00 \pm 0.00 & \text { c }\end{array}$ & C $7.00 \pm 0.50$ \\
\hline 28 & A $80.20 \pm 3.11 \mathrm{a}$ & $\begin{array}{lll}\text { B } & 0.00 \pm 0.00 & \mathrm{c}\end{array}$ & C $0.00 \pm 0.00$ \\
\hline
\end{tabular}

$\mathrm{LSD}=10.75$

Capital letters denote differences $\mathrm{P}<0.05$ among groups.

Small letters denote differences $\mathrm{P}<0.05$ between means.

\section{Sperm Concentration:}

The mean values of sperm concentration were clarified in table (6). The values tend to suppress dramatically

$\mathrm{P}<0.05$ mainly on day 21 in chemical group and on day 28 in ligation group, which it reached $(0.00 \pm 0.00)$.

Table (6). Shows the values of sperm concentration $\left(\ldots . \mathrm{X} 10^{9}\right)$ in bucks.

$\mathrm{LSD}=0.11$

\begin{tabular}{|c|c|c|c|}
\hline Time & $\begin{array}{l}\text { Control group } \\
\mathrm{M} \pm \mathrm{SE}\end{array}$ & $\begin{array}{c}\text { Chemical group } \\
\mathrm{M} \pm \mathrm{SE}\end{array}$ & $\begin{array}{c}\text { Ligation group } \\
\mathrm{M} \pm \mathrm{SE}\end{array}$ \\
\hline 7 & A $1.50 \pm 0.17 \mathrm{a}$ & B $0.39 \pm 0.02 \mathrm{a}$ & C $0.58 \pm 0.03 \mathrm{a}$ \\
\hline 14 & A $1.55 \pm 0.12 \mathrm{a}$ & B $0.13 \pm 0.04 b$ & C $0.37 \pm 0.05 \mathrm{~b}$ \\
\hline 21 & A $1.52 \pm 0.16 \mathrm{a}$ & B $0.00 \pm 0.00 \mathrm{c}$ & C $0.20 \pm 0.01 \mathrm{c}$ \\
\hline 28 & A $1.53 \pm 0.14 \mathrm{a}$ & B $0.00 \pm 0.00 \mathrm{c}$ & $\begin{array}{lll} & 0.00 \pm 0.00 \mathrm{~d}\end{array}$ \\
\hline
\end{tabular}

Capital letters denote differences $\mathrm{P}<0.05$ among groups.

Small letters denote differences $\mathrm{P}<0.05$ between means.

\section{Sperm Viability:}

Table (7) illustrated the mean values of sperm viability. High percent of live sperms $(38.22 \pm 2.35)$ detected in the first ejaculate of the control group. Within the treatment groups, similar findings as mentioned for sperm concentration were recorded.

Table (7). The values of sperm viability (\%) in bucks.

\begin{tabular}{|c|c|c|c|}
\hline Time (day) & $\begin{array}{c}\text { Control group } \\
\mathrm{M} \pm \mathrm{SE}\end{array}$ & $\begin{array}{c}\text { Chemical group } \\
\mathrm{M} \pm \mathrm{SE}\end{array}$ & $\begin{array}{c}\text { Ligation group } \\
\mathrm{M} \pm \mathrm{SE}\end{array}$ \\
\hline 7 & A $83.22 \pm 2.35 \mathrm{a}$ & B $40.25 \pm 4.52 \mathrm{a}$ & C $50.50 \pm 3.75$ a \\
\hline 14 & A $80.50 \pm 0.26$ a & B $15.75 \pm 2.43 \mathrm{~b}$ & C $35.44 \pm 2.28$ b \\
\hline 21 & A $78.75 \pm 0.45$ a & $\begin{array}{lll}\text { B } & 0.00 \pm 0.00 \quad \text { c }\end{array}$ & C $8.63 \pm 4.19$ \\
\hline 28 & A $80.34 \pm 0.31 \mathrm{a}$ & B $0.00 \pm 0.00 \quad$ c & C $0.00 \pm 0.00$ \\
\hline
\end{tabular}

$\mathrm{LSD}=9.3$

Capital letters denote differences $\mathrm{P}<0.05$ among groups.

Small letters denote differences $\mathrm{P}<0.05$ between means.

\section{Microscopical Findings: \\ Control Group:}

Testicular section showed normal arrangement of germ cells (spermatogonia) on the basement membrane of the seminiferous tubules also presence of sertoli cells. There are distinct peritubular spaces between the tubules which contain leydig cells (Figure 3).

\section{Treatment Groups:}

\section{One Month:}

The microscopical picture of testis in chemical group showed mineraliza-tion and hyalinization of the seminiferous tubules (Figure 4). In ligation group, testis display infracted areas enclosed by inflammatory zone consisting mainly of neutrophils and thrombosed blood vessels 
with mineralization of the seminiferous tubules and vacuolar degeneration of the spermatogonia (Figure 5).

Two Months:

Histopathological section of testis, two month post- injection of formalin reflected severe fibrosis, surrounding the empty and atrophied seminiferous tubules
(Figure 6). Testis subjected to ligation revealed degeneration of the seminiferous tubules which appeared in irregular shape surrounded by fibrosis. Also depletion of both germinal and sertoli cells leaving only basement membrane, in addition, absent of leydig cells in the interstitial space (Figure 7).

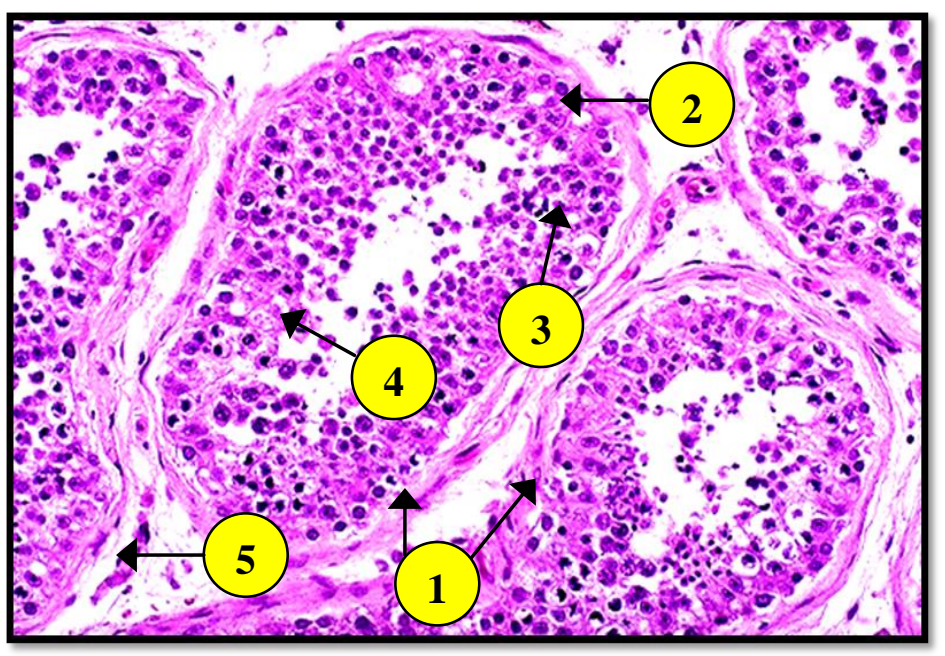

Figure. (3). Histology of testis related to control group showed seminiferous tubules (1) lined by basement membrane containing spermatogonia (2), below it the sertoli cells(3), different stages of spermatozoa(4) in the lumen and interstitial tissue between the tubules containing leydig cells (5) (H\&E X 10).

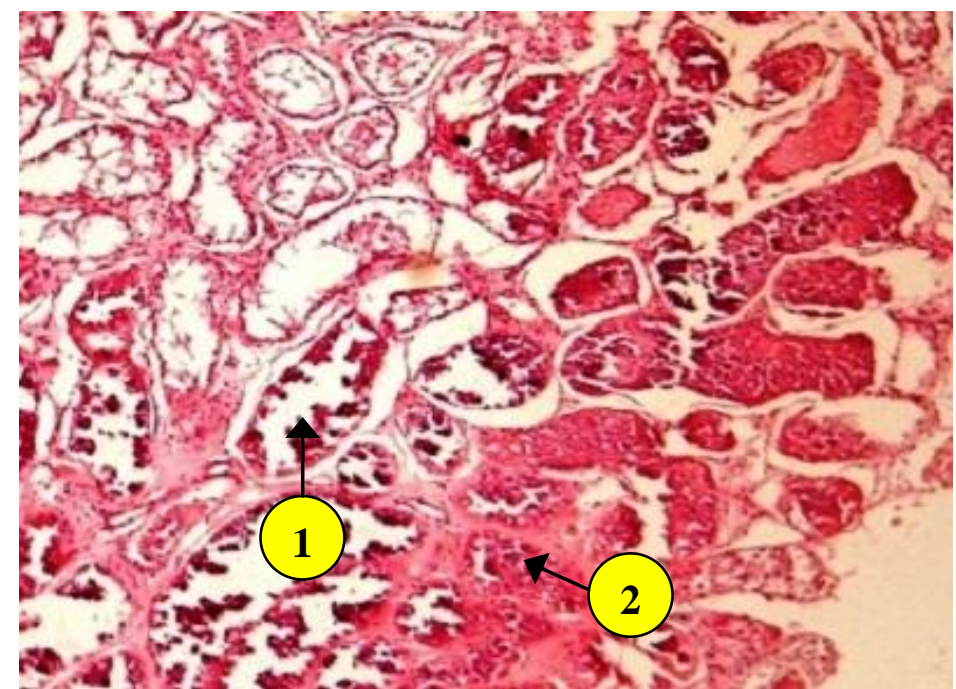

Figure (4). Microscopical picture of testis, one month post formalin injection showed mineralization (1) and hyalinization (2) of the seminiferous tubules. (H \& E x 10) 


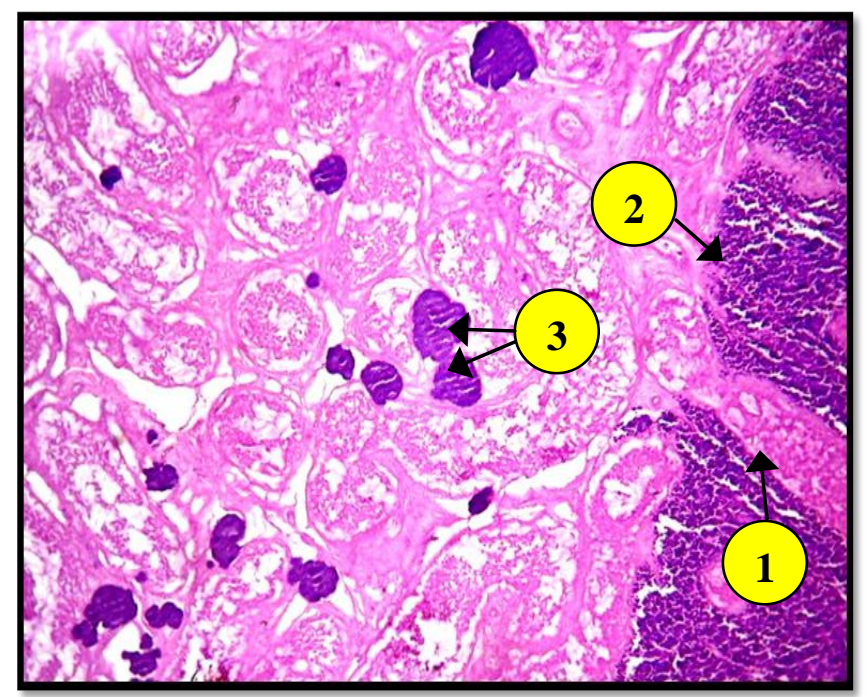

Figure (5). Microscopical picture of the testis, one month post-ligation showed infracted area(1) surrounded by inflammatory zone (2), mineralization of the seminiferous tubules (3). (H\&E X 10).

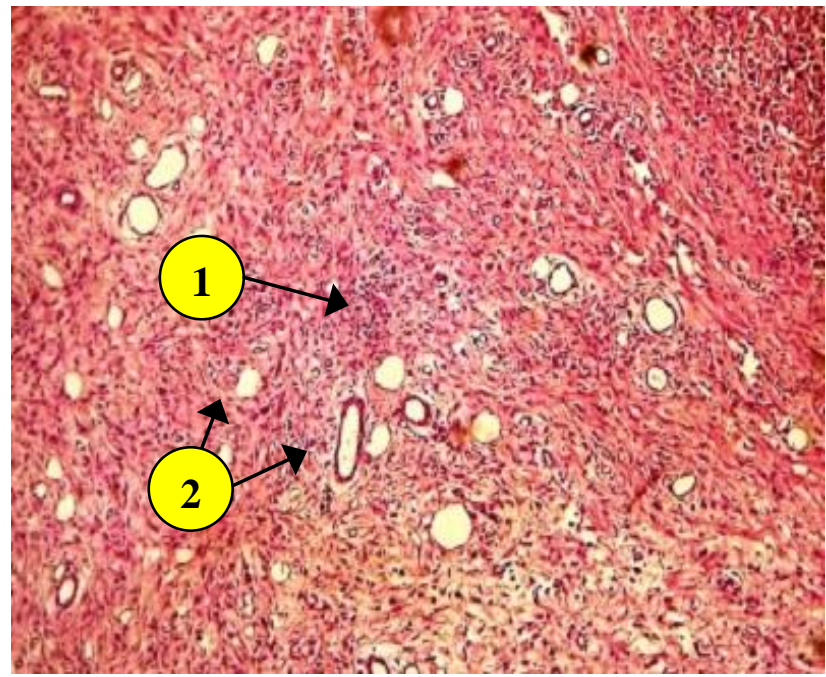

Figure (6). Microscopical picture of the testis, two months post-formalin injection showed severe fibrosis (1) surrounding the empty and atrophied seminiferous tubules (2) (H\&E X 10).

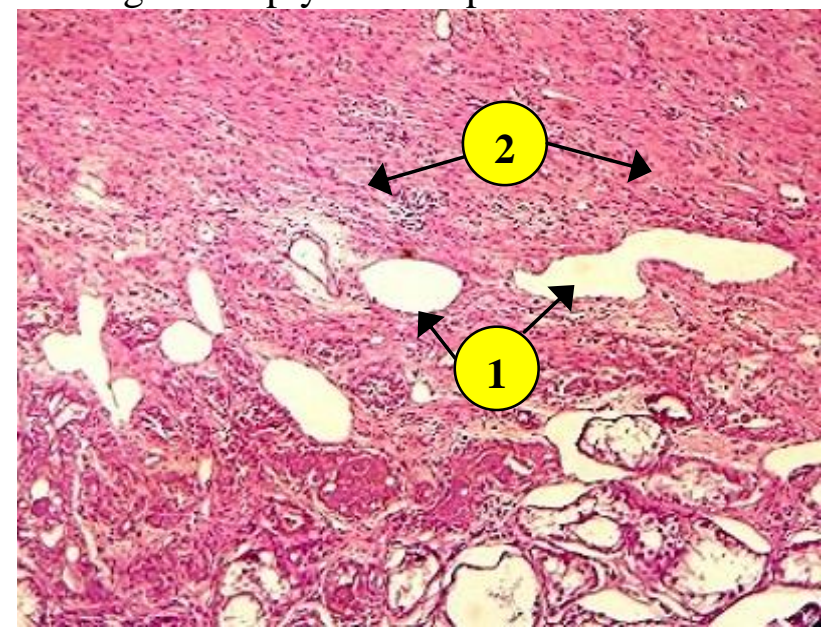

Figure (7). Microscopical picture of the testis, two months post-ligation showed irregular shape and empty seminiferous tubules (1) surrounded by interstitial fibrosis (2) which replaced the leydig cells (H\&E X 10). 


\section{Discussion}

Numerous trials and evaluation have been carried with surgical castration worldwide in animals. This technique usually associated with serious complications such as bleeding and evisceration or even death (2). To avoid the complications of surgery, We tried to perform an alternative method of surgical castration represented by chemical castration and external ligation of spermatic cord and because there is no available reference on the later so, it regarded as a novel technique for veterinary castration.Chemical castration needed a shorter time to perform when compared with the external ligation of spermatic cord, although both techniques necessitated shorter time compared with surgical type which can be done within a time not less than $(10 \pm 2.0)$ minutes/testis (12). The short time of the two present techniques is important when try to castrate a herd of animals, in which the injection or ligation method is cleaner, done rapidly also with low cost (more economic) and easily performed (not need a specialist surgeon).Clinical follow-up reflected four types of complications which included testicular swelling, hydrocele, scrotal ulcer and lameness. Testicular swelling is an expected reaction to injection or ligation resulting in acute inflammation (acute orchitis) which characterized by congestion and edema, thus increase forced that tend to move fluid from intra-vascular compartment into the interstitial tissue. Signs of swelling and firmness of the testes had been reported in many previous researches concerning nonsurgical castration (10). Hydrocele happened in two bucks related to ligation group. A hydrocele may represent an imbalance in the secretary and absorptive capacity of the layers of tunica vaginalis as a result of an inflammatory reaction. Similar finding noticed by (11), who stated that hydrocele might accompany torsion of the spermatic cord in rams.Two animals injected formalin showed scrotal ulcer. One animal had pre-existing scrotal skin irritation prior to injection. While the second animal move during injection, thus sedation and good restraining of animal is important to minimize movement. Also slow injection technique must be used to avoid leakage of the drug from injectable site.Severe scrotal ulceration recorded by (12) when injected lactic acid into 50 lambs, $4 \%$ of which required surgical intervention. While (13) injected $10 \%$ of calcium chloride in 32 lambs, scrotal ulceration was evident in four animals (all required testicular removal).Lameness may be attributed to pain evocated from injection or ligation. Michelle and Anna (14), stated that the nerve endings associated with pain sensation are located on the scrotal skin and in the capsule of the testis rather than within testicular parenchyma. In pigs, (15) noticed that injection of zinc tannate is neurotoxic, cause convulsions, loss of coordination and sometimes death.

\section{Testosterone Assay:}

The two various techniques caused a significant drop $\mathrm{P}<0.05$ in serum testosterone concentration. It seems that intra-testicular injection or cord ligation harm leydig cells function in terms of ability to respond to $\mathrm{LH}$ and produce testosterone. The lack of response to gonadotropin in treated bucks suggests that leydig cells in those animals were atrophied or unable to respond. This outcome is in accordance with previous study demonstrating the effect of luteinizing hormone-releasing hormone (LH-RH) immunization on testicular steroidogenesis in bull (16). In an experimental works by (4), who immunized pigs against (LH-RH). The result indicated reduction in $\mathrm{LH}$ receptor in the testis and reduces ability of leydig cells to produce testosterone.A comparative study by (1) for evaluation of the outcome of bull castration by intra-testicular injection of ethanol and calcium carbonate and their effect on serum testosterone concentration. The result reflected significant $\mathrm{P}<0.05$ reduction of this hormone in ethanol group. On the other 
hand, calcium chloride injection was not altered $\mathrm{P}>0.05$ in testosterone level.

\section{Semen Evaluation:}

Semen volume was significantly $\mathrm{P}<0.05$ declined in treatment groups and there were seminal plasma only with the advancement of time. This may be ascribed to stress of castration which cause destruction of the sertoli cells in the seminiferous tubules, which is responsible for sperm production. Such observation had been recorded by (7).Sperm motility decreased dramatically $\mathrm{P}<0.05$ in treatment groups. This suggests that there is a positive effect of decreasing amount of seminal plasma on sperm motility. This presumption is in accordance with result from a study on bovine sperm (17).Sperms concentration reached zero on day 21 in chemical group and on day 28 in ligation group. This result is expected as there was a positive correlation between this parameter and semen volume. This finding is supported by a study in rams (18).Semen viability in the treatment groups showed the same findings mentioned for sperm motility and concentration and the causes were similar. In addition, I thought that closing of the outlet from the testis or intra-testicular injection invariable lead to degeneration of the germinal tissues of the testis and this was clear in histopathological sections of the testis.
Hacker et al., (19) referred to several factors which can affect the viability such as physical damage to the testis or has gone through radiation treatment of the testis or exposure to certain drugs.

Microscopical Findings:

Microscopical sections of the testes revealed an increase in regressed seminiferous tubules in treated bucks. A much higher percent of germ cells deficient tubules or empty tubules observed in bucks, two months post treatment, suggesting that the spermatogonia stem cells were destroyed over the treatment that may allow for filling with a germ cells suspension. Thus, could not reinitiate spermatogenesis in these seminiferous tubules. Also the interstitial tissue shows hardly changes represented by fibrosis especially in chemical group which may be due to severe inflammation and due to ischemia resulted from ligation of spermatic cord. These interpretations also mentioned by (20), (21).On conclusion, these two clinical trials were characterized by its simplicity, safety; free from obvious skin incision with a document no death. It gives stimulation to the veterinarian in the field to perform these methods of castration rather than traditional methods which are usually accompanied by serious healthproblems.

\section{References}

1. Canpolat, I.; Gur, S.; Gunay, C.; Bulut, S. and Eroksus, H. (2006). An evaluation of the outcome of bull castration by intra-testicular injection of ethanol and calcium carbonate. Rev. Med. Vet., 157, 8 (9): 420-425.

2. Burciage, R.L.; Step, D.L.; Holland, B.P.; McCurdy, M.P. and Krehbiel, C.R. (2006). Castration in goats: Technique and animal welfare issues. Compend. Cont. Edu. Pract. Veterinarian, 24 (9): 512-515.

3. Sharpe, R.M. (1990). Intra-testicular control of steroidogenesis. Clin. Endoc., 33:787-807.
4. Giri, S.C.; Yadav, B.P. and Panda, S.K. (2002). Chemical castration in pigs. Ind. J. of Anim. Sci., 72 (6): 451-453.

5. Conventry, J.; McEwan, D. and Bettam, J.D. (1990). Sterilization of bull with lactic acid. Aust. Vet. J., 66 (5): 156-157.

6. Chakraborty, P.K.; Stuart, L.D. and Brown, J.L.(1989). Puberty in the male goat : Serum concentration of LH, FSH and Testosterone from birth through puberty and semen characteristics at sexual maturity. Anim. Reprod. Sci., 2:91-101.

7. Bearden, H.J. and Fuquay, J.W. (1997). Semen evaluation. Appl. Anim. 
Reprod. $4^{\text {th }}$ (ed). Prentice Hall, N. J., Pp: 158-169

8. Prophet, E.B.; Mills, B. and Arrington, J.B.(1992). Laboratory methods in histotechnology. Washington: Armed Forces Institute of Pathology, P: 275.

9. Snedecor, G.W. and Cochran, W.G.(1973). Statistical Methods. $6^{\text {th }}$ (ed). The Iowa State University Press, Pp: 238-248.

10. Costa, F.L.; Silva, S.M. and Nascimento, E.F. (2007). Pathologic evaluation of testis and epididymis of hairy rams. Arq. Bras. Med. Vet. Zootec., 59(5): 1110-1116.

11. Beiko, D.T.; Kim, D. and Morales, A. (2003). Aspiration and sclerotherapy versus hydrocelotomy for the treatment of hydrocele. Urology, 61:708712.

12. Stafford, K. (2007). Castration of older lambs with lactic acid referring to their complications. Vet. J, 173: 477-481.

13. Melches, S., Mellema, S.C.; Doberr, M.G.; Wechaler, B. and Steiner, A. (2008). Castration in lambs over 10 weeks of age with intratesticular injection of calcium chloride. Vet. J., 186: 323-340.

14. Michelle, K. and Anna, W. (2006). Non-surgical methods of contraception and sterilization. Theriogenology, 66: 514-525.

15. Taylor, A.A.; Weary, D.M.; Lessard, M. and Bralthwalte, L.A. (2001).
Behavior responses of piglets to castration: the effect of pig age. Appl. Anim. Behav. Sci, 73: 3545.

16. Aissat, D.; Sosa, J.M.; Avila, D.M.; Bertrand, K.P. and Reeves, J.J. (2008). Endocrine, growth and carcass characteristics of bull immunized against LH-RH fusion protein. J. Anim. Sci.; 80:22092213.

17. Graner, D.L.; Thomas, C.A.; Marshall, C.E. and Allen, C.H. (2011). Seminal plasma addition attenuates the dilution effect in bovine sperm. Theriogenology, 56(1):31-40.

18. Jenning, J.J. and McWeeney, J.(1976). Effect of frequent ejaculation on semen characteristics in rams. Vet. Res., 98:230-233.

19. Hacker, U.B.; Kohnlein, W. and Gohde, W. (2000). Effect of single and split dose of cobalt-60 gamma ray on mouse stem cell spermatogonia. Radiol. Res.; 154:667-672.

20. Kuntz, A.S. (1992). Degenerative changes in the seminal epithelium and associated hyperplasia of the interstitial tissue in the mammals' testis. Endocrinology, 5:190-204.

21. Weisgold, A.D. (1997). Reproductive capacity of beef bull. Daily spermatozoa production, spermatozoa reserves, dimensions and weight of reproductive organs. J. of Anim. Sci., 48:351358. 


\section{الاخصاء غير الجراحي في ذكور الماعز الزئز}

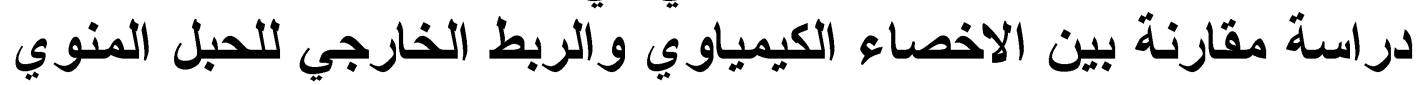

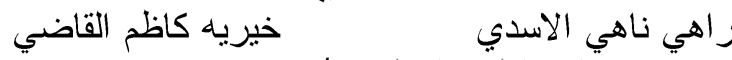

$$
\begin{aligned}
& \text { كلية الطب البيطري / جامعة بغداد }
\end{aligned}
$$

هدف البحث إلى تقييم فعالية حقن مادة الفورمالين داخل الخصية وكذلك الربط الخارجي للحبل المنوي لإحداث العقم في

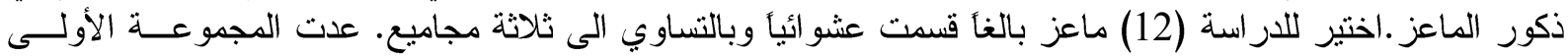

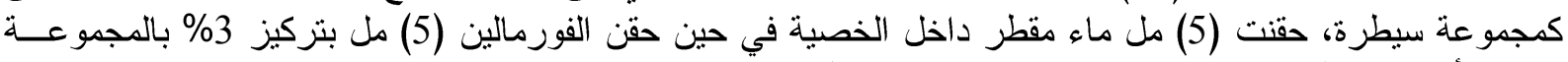

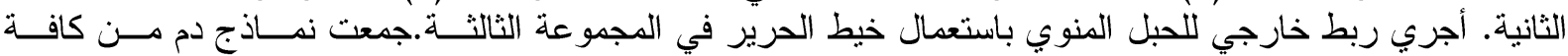

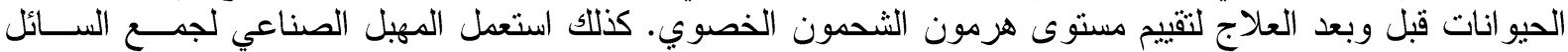

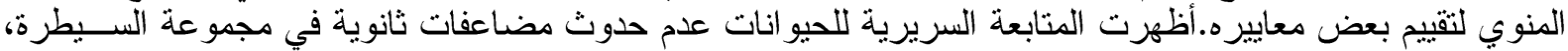

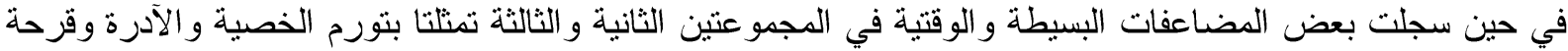

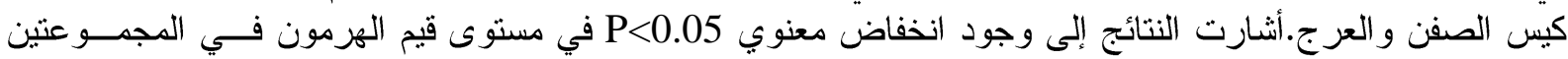

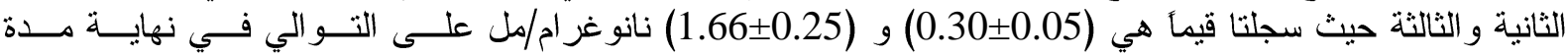

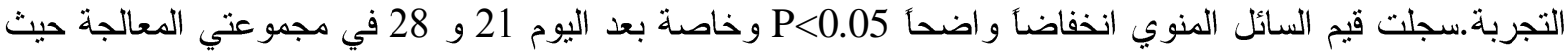

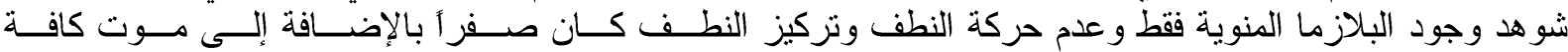

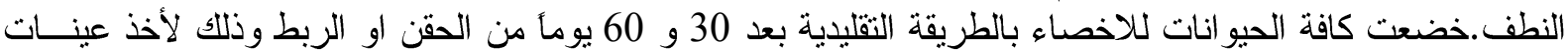

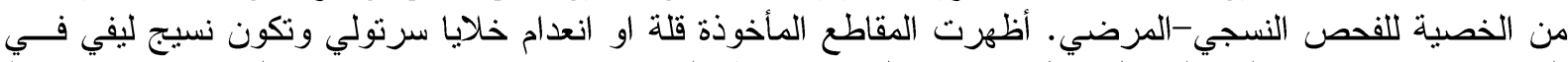

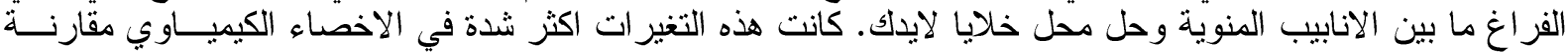

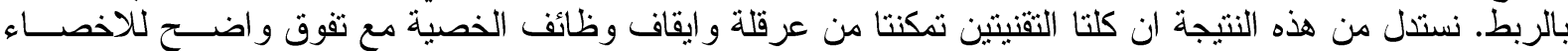
الكيمياوي. 